Stratigraphic Revision of the Middle Eocene, Oligocene, and Lower MioceneAtlantic Coastal Plain of North Carolina

GEOLOGICAL SURVEY BULLETIN I 457-F 



\section{Stratigraphic Revision of the Middle Eocene, Oligocene, and Lower Miocene- Atlantic Coastal Plain of North Carolina}

By LAUCK W. WARD, DAVID R. LAWRENCE, and BLAKE W. BLACKWELDER

A lithostratigraphic study of carbonate and clastic Eocene to lower Miocene rocks on the North Carolina Coastal Plain

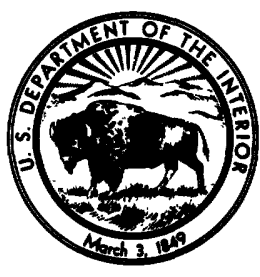




\section{UNITED STATES DEPARTMENT OF THE INTERIOR}

GECIL. D. ANDRUS, Secretary

GEOLOGICAL SURVEY

H. William Menard Director

\section{Library of Congress Cataloging in Publication Data}

Ward, Lauck W

Stratigraphic revision of the middle Eocene, Oligocene, and lower MioceneAtlantic Coastal Plain of North Carolina.

(Contributions to stratigraphy) (Geological Survey bulletin ; 1457-F)

Bibliography: p.

1. Geology, Stratigraphic-Eocene. 2. Geology, Stratigraphic-Oligocene. 3. Geology, Stratigraphic-Miocene. 4. Geology-North Carolina. I. Lawrence, David R., joint author. II. Blackwelder, Blake W., joint author. III. Title. IV. Series. V. Series: United States. Geological Survey. Bulletin ; 1457. QE75.B9 no. 1457 [QE692.2] 557.3'08s [551.7'8] 78-606092

For sale by Superintendent of Documents, U.S. Government Printing Office Washington, D.C. 20402

Stock Number 024-001-03129-9 


\section{CONTENTS}

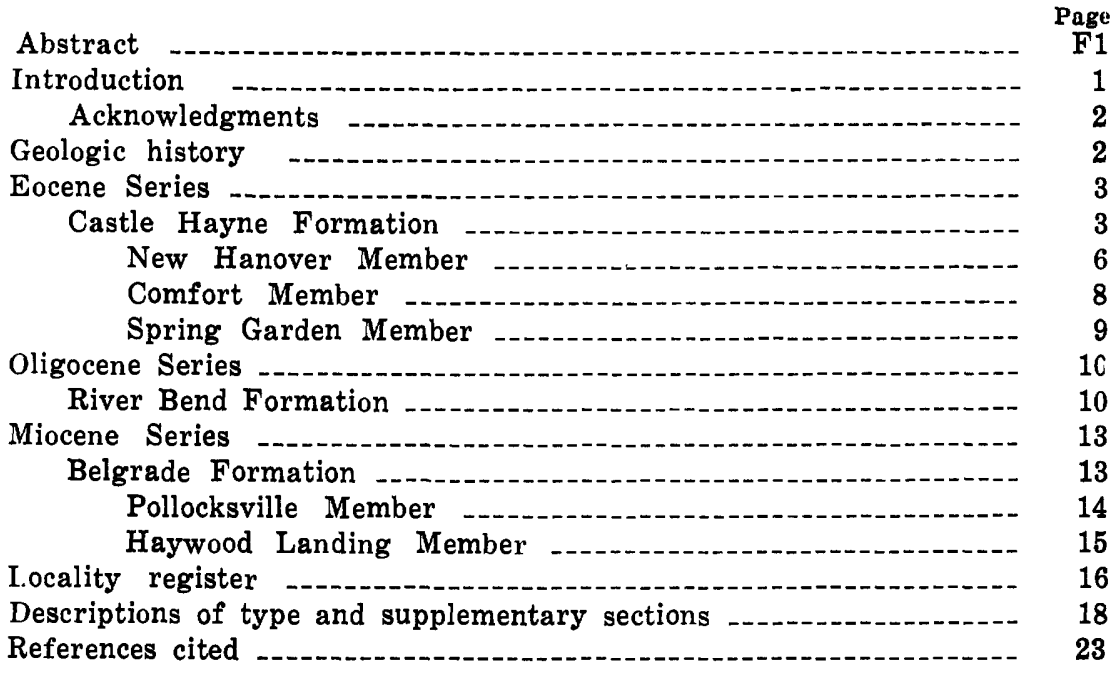

\section{ILLUSTRATIONS}

FIgURE 1. Composite section of outcropping Tertiary formations studied in this report

2. Base map showing basin configurations and localities

3. Correlation chart of the Paleocene, Eocene, Oligocene, and Miocene stratigraphic units 



\title{
STRATIGRAPHIC REVISION OF THE MIDDLE EOCENE, OLIGOCENE, AND LOWER MIOCENE-ATLANTIC COASTAL PLAIN OF NORTH CAROLINA
}

\author{
By Lauck W. Ward, David R. Lawrence, ${ }^{1}$ and \\ Blake W. BLACKWELDER
}

\begin{abstract}
A review of past work on the Eocene, Oligocene, and lower Miocene sediments of the Coastal Plain of North Carolina, together with fieldwork in that area, has indicated the necessity of a thorough stratigraphic revision of those beds. The Castle Hayne Formation (middle Eocene) is redefined and divided into three units-the New Hanover, the Comfort, and the Spring Garden Members. It is recommended that the name Trent Marl be abandoned. Beds previously assigned to the Trent Marl are placed in the Castle Hayne and in two new formations, herein described as the River Bend Formation (middle and upper Oligocene) and the Belgrade Formation (lower Miocene). The Belgrade Formation is divided into two units-the Haywood Landing and the Pollocksville Members. Lithologies, areal distributions, stratigraphic relationships, ages, correlations, and outcrop descriptions are given for the three formations.
\end{abstract}

\section{INTRODUCTION}

Our stratigraphic studies in eastern North Carolina during 1976-77 have enabled us to describe the depositional history from Eocene to Miocene time. The inadequacy of previous lithostratigraphic terminology had obscured much of this geologic history, and a stratigraphic revision was necessary. Most of the work of the 19th-century geologists in the Coastal Plain of North Carolina concerned the age assignments of various exposed units. The

1 Department of Geology, University of South Carolina, Columbia, S.C. 
20 th century marked the first attempts at lithostratigraphic division of the Coastal Plain. Miller $(1910,1912)$ was the first to divide the North Carolina limestones into formations. Kellum (1925, 1926) later revised Miller's stratigraphy but failed to provide an adequate lithostratigraphic scheme. Different beds of Eocene, Oligocene, or Miocene age were still included within one unit. Later attempts to revise the stratigraphy were informal or relied too much upon the earlier assignments of Miller and Kellum. Generally, the units have remained rather loosely defined and not related to specific type sections.

\section{ACKNOWLEDGMENTS}

The authors would like to thank C. H. Lee and D. S. VanNieuwenhuise, both of the University of South Carolina, for their help in the field. Technical support on the various fossil taxa was given by J. E. Hazel, C. W. Poag, L. M. Bybell, and N. O. Frederiksen, of the U.S. Geological Survey, and P. M. Kier of the Smithsonian Institution. Our special thanks to P. M. Philips and the operators of the Martin Marietta Corp. quarries at New Bern, Belgrade, and Castle Hayne, N.C.; also David Brisley of the Georgetown Plant, S.C. Most cooperative were the personnel of the East Coast Limestone Quarry, N.C. Lime Inc. Quarry, Ideal Cement Co. Quarry, B. B. Fussell Co., Inc., Quarry, and the Atlantic Limestone Co. Quarry.

\section{GEOLOGIC HISTORY}

Overlapping the eroded surface of the Upper Cretaceous rocks on the North Carolina Coastal Plain, a middle Eocene (Claibornian) sea transgressed as far west as the Piedmont. A thick sequence of limestone was deposited in this shallow tropical marine basin. This limestone constitutes the Castle Hayne Formation (herein redefined) and consists largely of size-sorted, sometimes crossbedded, bryozoan hash. During the late middle Eocene, the Castle Hayne sea regressed as the Cape Fear arch to the south and the Norfolk arch to the north became positive. During this regression, an arenaceous molluscan limestone (the Spring Garden Member of the Castle Hayne) was deposited in the Neuse River area.

During the late Eocene (Jacksonian) and early Oligocene (early Vicksburgian), the exposed Eocene carbonate rocks on the Coastal Plain of North Carolina were eroded subaerially. This erosion pro- 
duced an uneven surface and removed the Castle Hayne entirely in some areas. A middle Oligocene (late Vicksburgian) transgression centered in the area of the Neuse River and persisted through the late Oligocene (Chickasawhayan). Covering less than a tenth of the area overlapped by the Castle Hayne sea, this Oligocene sea was shallow near its perimeter, where barnacleshell hash limestone is commonly crossbedded (herein termed the River Bend Formation).

Uplift of the Coastal Plain at the end of the late Oligocene (Chickasawhayan) again exposed the carbonate sequences of the Castle Hayne and the newly deposited sediments of the River Bend to subaerial solution and erosion.

During the latest Oligocene or earliest Miocene, a small marine embayment evolved in the Jones, Onslow, Carteret, and Craven Counties area. Normal-saline seas overlapped part of the now well-indurated River Bend limestone. Marine currents swept the underlying limestone clear of sediment, while marine mollusks bored the exposed rock substrate. A thin phosphate coating formed on the limestone surface, and marine oysters attached to this substrate. As an offshore bar became prominent, quartz-rich sandy sediment was deposited in the basin.

Contained fossils indicate that the basin was at first of nearnormal salinity. As the barrier prograded seaward, salinities decreased, and groups restricted to normal marine conditions disappeared, while the oyster, Crassostrea, thrived in this sand, herein named and described as the Pollocksville Member of the Belgrade Formation.

During the early Miocene, a small marine transgression eroded the mollusks from the Pollocksville Member into the open marine deposits of the Haywood Landing Member of Belgrade Formation (herein named and described). The Haywood Landing sea did not transgress over the full area covered by the Pollocksville sediments, and, as a result, these marginal marine deposits are preserved in the northern and northwestern perimeter of the Belgrade Formation. Figure 1 is a composite section showing the outcrop record compiled from localities shown in figure 2.

\section{EOCENE SERIES}

\section{CASTLE HAYNE FORMATION}

The following redefinition of the Castle Hayne Formation is proposed because of the ambiguous nature of the original descrip- 


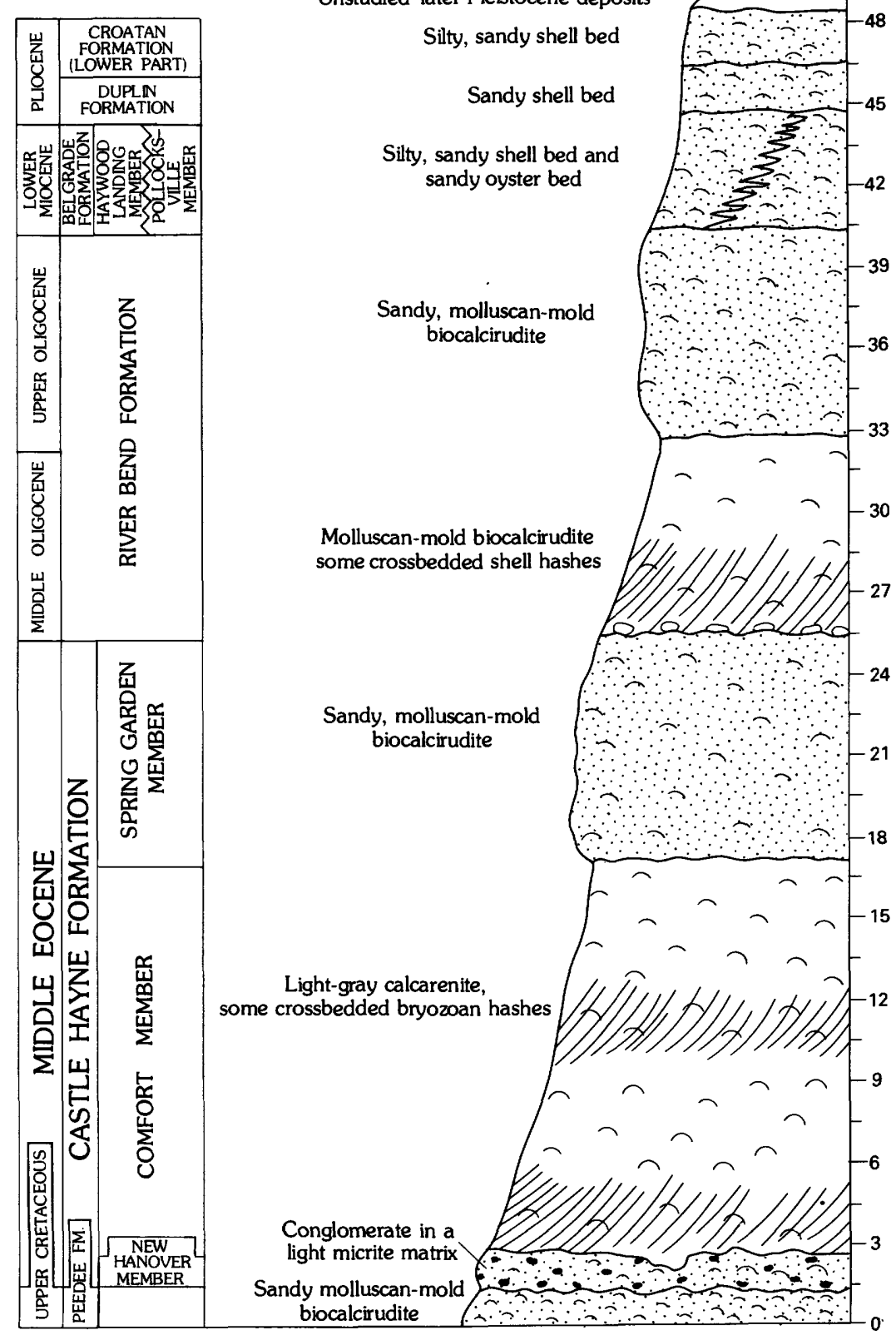

FIgURE 1.-Composite section of outcropping Tertiary formations studied in this report. 


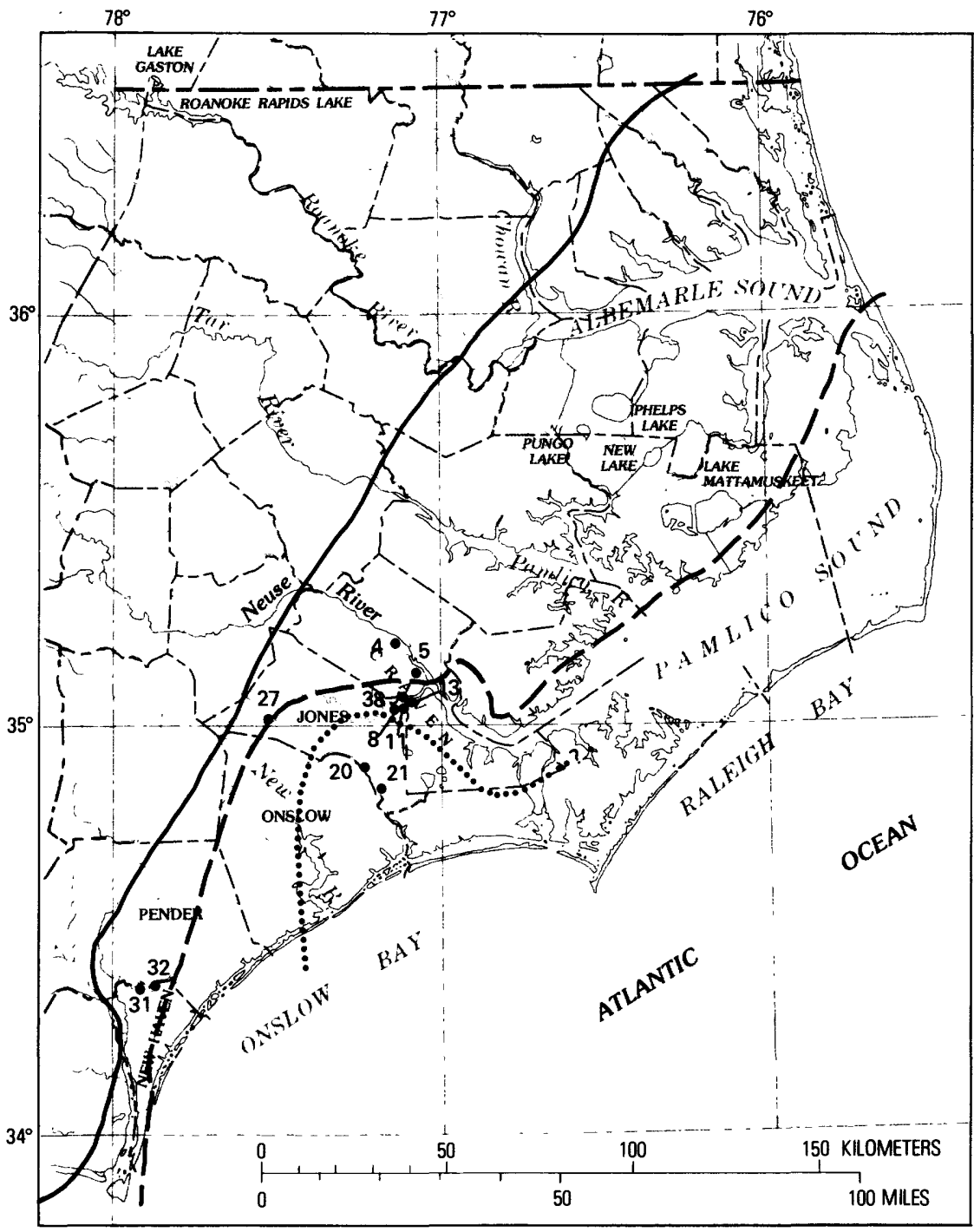

Figure 2.-Base map showing basin configuration of the Castle Hayne (solid line), River Bend (dashed line) and Belgrade (dotted line) formations. Locations of type and reference sections are numbered.

tion (Miller, 1910, 1912), the lack of a type locality, and the failure of subsequent studies (Kellum, 1925, 1926; Cooke and MacNeil, 1952; LeGrand and Brown, 1955) to clearly define the limits and various units of the formation.

The Castle Hayne Formation was named for limestone near 
Castle Hayne in New Hanover County, N.C. The Ideal Cement Co. quarry just east of Castle Hayne, New Hanover County, N.C. (loc. 32, fig. 2), is here designated the type locality of the Castle Hayne. The formation is redefined to include three new members: phosphatic lithocalcirudite facies (New Hanover Member), bryozoan and echinoidal biocalcarenite facies with micrite matrices (Comfort Member), and siliceous pelecypod-mold biocalcirudite facies (Spring Garden Member).

\section{NEW HANOVER MEMBER}

The name New Hanover Member is proposed for a slightly arenitic, micritic, phosphatic lithocalcirudite. This member consists of cobble- to pebble-sized, sandy, calcareous clasts, usually subrounded to well-rounded and often coated with phosphate and glauconite. Occasional quartz pebbles and flat clay chips are also present, along with very fine sand, glauconite, and phosphate in a cream-colored micrite matrix. Common ingredients also are shark and ray teeth, occasional worn bone, calcitic mollusks such as Pecten and Ostrea, echinoids, crabs, and molluscan molds. The New Hanover Member ranges in thickness from 0 to $2 \mathrm{~m}$.

Best exposures of the New Hanover are in three large quarries in the Castle Hayne area (locs. $30,{ }^{2} 31$, and 32). The Martin Marietta quarry in New Hanover County (loc. 31) is here designated the type locality for the New Hanover Member. The New Hanover is easily delineated from the underlying Peedee Formation, a gray mold-and-cast siliceous limestone of middle Maestrichtian (Late Cretaceous) Age. The New Hanover occupies erosional channels in the Peedee. The contact between the two is sharp, and much of the conglomeratic material in the New Hanover was derived from the underlying Cretaceous. Clasts in the New Hanover fine upward.

The uneven upper surface of the New Hanover is apparently due to erosion after lithification, and it is overlain by the sharply contrasting bryozoan biocalcarenite of the Comfort Member. The two members are nowhere seen to grade; they have an abrupt, uneven contact. There was apparently only a short hiatus between deposition of the New Hanover and that of the overlying unit. The New Hanover contains molluscan molds of nautiloid cephalopods, gastropods, and various bivalve species, many of which also occur in the overlying Comfort Member. The presence of Cubitostrea

2 Only type and reference sections are shown in fig. 2. 
ATLANTIC COASTAL PLAIN OF NORTH CAROLINA

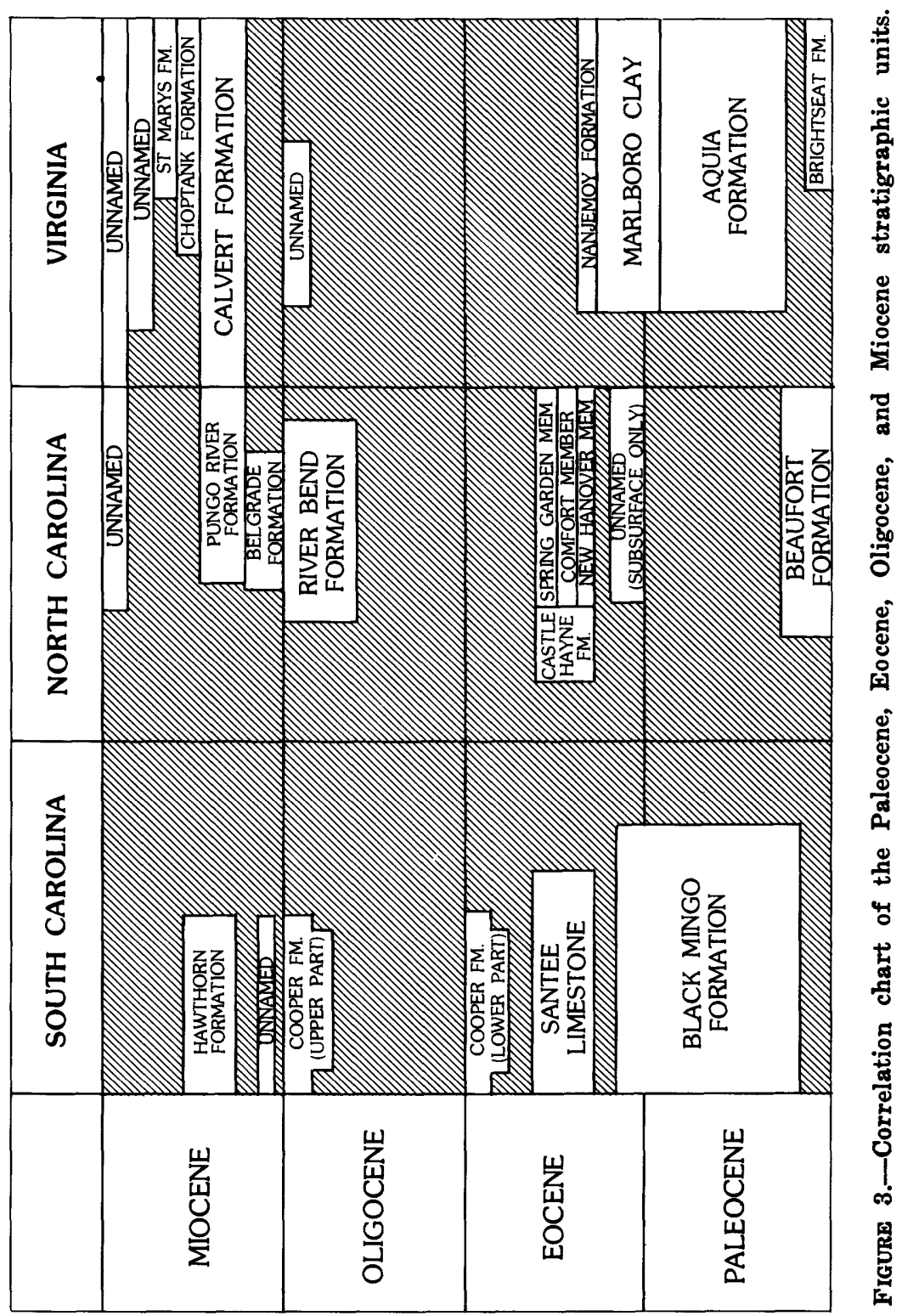


sellaeformis in the New Hanover Member at locality 31 suggests that this unit is middle middle Eocene and is equivalent to the Lisbon Formation of Alabama. Figure 3 shows the correlation of this unit with other Coastal Plain units.

\section{COMFORT MEMBER}

The name Comfort Member is proposed for a gray to creamcolored, bryozoan-echinoid calcirudite, grading to a fine calcarenite, containing small admixtures of fine quartz, detrital and authigenic glauconite, and some detrital phosphate. This member consists of several depositional cycles, which begin with a medium to fine bryozoan and echinoid fragmental calcirudite and grade upward to a fine calcarenite. Glauconite and phosphate pebble concentrations mark breaks in deposition. Under increased energy conditions, deposition resumed, resulting in coarse bryozoan hashes above the glauconite and phosphate pebble beds. The Comfort Member is generally soft and friable but locally may be cemented by a dense micrite matrix. The N.C. Lime Excavating Co. quarry at Comfort, Jones County (loc. 27), is designated as the type locality. The Comfort Member is the most widespread of the Castle Hayne units (see fig. 2). The best localities are in several quarries (locs. 27-32).

The Comfort ranges in thickness from approximately $3 \mathrm{~m}$ at Maple Hill and Castle Hayne (locs. 30, 31) to at least $10 \mathrm{~m}$ at Rose Hill (loc. 28), Magnolia (loc. 29), and Comfort (loc. 27), and probably accounts for about half of the $260 \mathrm{~m}$ of the middle Eocene reported by Brown and others (1972) in the subsurface in the Core Sound, N.C., area.

The Comfort Member unconformably overlies the New Hanover Member in the southern part of the basin at the previously mentioned quarries (locs. 30, 39, 31, 32). Below Goldsboro on the Neuse River (loc. 46) and on Moseley Creek (loc. 47), the Comfort Member overlies the sandy, argillaceous sediments of the Beaufort Formation (Paleocene); this is also true in the subsurface in the northeast area of the basin. In the more eastern counties, the Comfort Member directly overlies a sequence of lower Eocene carbonate rocks; to the west, it contains progressively more detrital quartz, consists of a limy sandstone in Johnston County (loc. 45), and is considered a nearshore, sandy facies.

The Spring Garden Member overlies the Comfort in the area of the Neuse River from Rock Landing (loc. 2) to New Bern (loc. 5) and near Trenton on the Trent River. At Biddle Landing (loc. 
1), lower Pliocene shelly sands of the Duplin Formation directly and unconformably overlie the Comfort Member, as is also true southward in the basin at Natural Well, Duplin County (loc. 43). On the New River (loc. 42), the Comfort is directly overlain by the calcarenite units of the River Bend Formation (Oligocene).

The Comfort Member is Claibornian (late middle Eocene) in age and is equivalent to the Gosport Sand of Alabama. Pecten membranosus Morton, found both in the Santee Limestone and the Comfort, is a senior synonym of Pecten wautubbeanus Dall found in the Claibornian of Alabama. Also common are Pecten clarkeanus Aldrich and Crassatella alta Conrad, both found only in Claibornian beds in Alabama.

\section{SPRING GARDEN MEMBER}

The name Spring Garden Member is proposed for tan to gray arenaceous molluscan-mold biocalcirudite along the Neuse River from Rock Landing (loc. 3) to New Bern (loc. 5) in Craven County. This gray and normally siliceous rock is well cemented by sparry calcite. Molluscan bivalve molds are partly or completely filled with silica, which forms siliceous pseudomorphs after the dominant mollusk, Macrocallista neusensis (Harris). Fine detrital phosphate is a common accessory in the member, in amounts as great as 5-10 percent. Molluscan bivalves originally accounted for as much as 75 percent of the rock. Spring Garden Landing (loc. 4) on the Neuse River, Craven County, is designated the type locality-a natural exposure of rock as much as $3 \mathrm{~m}$ thick. The Martin Marietta quarry at New Bern (loc. 5), where $6 \mathrm{~m}$ of well-indurated sandy limestone is exposed, is designated a supplementary reference locality.

The Spring Garden Member overlies the gray calcarenite of the Comfort Member conformably at Rock Landing (loc. 2), and is exposed above and below Rock Landing (loc. 3), at Spring Garden Landing (loc. 4), and at New Bern (loc. 5). At the Martin Marietta quarry in New Bern, the upper surface of the Spring Garden is extremely uneven because of solution and erosion. The surface is thinly coated by a veneer of phosphate upon which are attached middle Oligocene oysters. Overlying this surface is a tan barnacle hash in a calcarenite matrix, of Oligocene age, which ranges from 0 to $2 \mathrm{~m}$ in thickness and may be found in the molluscan molds and burrows in the top $7 \mathrm{~cm}$ of the Spring Garden Member. Because of erosion and channeling, shelly quartz sand of the Duplin Formation directly overlies the Spring Garden 
(middle Eocene) in the center of the pit, whereas on the flanks of the pit, the Duplin overlies Oligocene calcarenite deposits.

Along the Trent River, the Spring Garden overlies the Comfort Member and crops out intermittently from above Trenton to just below Prettyman Landing (loc. 44), where it dips below water level. At Prettyman Landing, the Spring Garden is overlain by the calcareous molluscan-mold sandy biocalcirudite of the River Bend Formation (Oligocene). The contact between the two units is sharply unconformable and is marked by a coarse conglomerate at the base of the River Bend.

The Spring Garden Member represents the latest Claibornian (latest middle Eocene). The molluscan assemblage is dominated by Macrocallista neusensis (Harris) (=Macrocallista perovata (Conrad)), which is a common Claibornian form. Also present are Crassatella alta Conrad and Bathytormus protextus (Conrad), both of which are known from the Gosport Sand of Alabama.

\section{OLIGOCENE SERIES}

\section{RIVER BEND FORMATION}

The name River Bend Formation is proposed for a series of limestones which were originally included in the Trent Marl by Miller (1910, 1912) and later in the Castle Hayne by Brown (1955) and LeGrand and Brown (1955). Kellum (1925, 1926) included some of these rocks in his treatment of the Trent and believed them equivalent to the unconsolidated sandy shell beds at Silverdale.

Because of the resulting confusion as to the specific identity of the Trent Marl, it is herein recommended that the name Trent be abandoned and that this limestone, which made up part of the original Trent, be given the name River Bend Formation. The River Bend Formation receives its name from the River Bend Estates (loc. 38) on the Trent River, Craven County.

The formation consists of biocalcarenite, molluscan-mold biocalcirudite, arenaceous barnacle hash, and very arenaceous pelecypod biocalcirudite. Near its base, in most areas, the River Bend contains little or no quartz sand and consists mainly of barnacle plates and molluscan molds in a calcarenite matrix. Toward the center of the basin, in the Trent and White Oak River areas, the River Bend Formation grades vertically into a very arenaceous, slightly phosphatic pelecypod biocalcirudite. This sandy limestone is similar to the Spring Garden Member of the Castle Hayne 
Formation, but the two are never in contact. Only the lower calcarenite facies of the River Bend is in contact with the Spring Garden, and the two units are easily distinguishable.

The River Bend Formation occupies the area outlined by Brown and others (1972) as Oligocene; it has maximum thicknesses of $150 \mathrm{~m}$ in the Cape Lookout area. The River Bend is approximately $3 \mathrm{~m}$ thick at the Martin Marietta quarry at New Bern (loc. 5) and is exposed intermittently along the Trent River from New Bern to Prettyman Landing (loc. 44). Large quarries at Belgrade, Onslow County (locs. 19, 20), have exposed $10 \mathrm{~m}$ of the very sandy limestone facies of the River Bend. Several small outcrops (locs. 23-26) on the New River at Camp Lejeune, Onslow County, are also assigned to the River Bend Formation.

The River Bend Formation crops out along the Trent River in the area of River Bend Estates, Craven County, where the barnacle calcarenite, the biocalcirudite, and the upper very arenitic molluscan-mold biocalcirudite facies may be seen. The exposure here at Rhems Landing (loc. 38) is designated the type locality. The right bank of the Trent River $0.5 \mathrm{~km}$ below Bells Landing and just below the mouth of Raccoon Creek is designated as a supplementary reference locality for the River Bend (loc. 13). Another supplementary reference locality, the right bank of the Trent River, $0.4 \mathrm{~km}$ below the mouth of Clayhill Branch, is selected to demonstrate the nonsiliceous lower beds of the formation (loc. 11). These beds may also be seen at locality 12 on the left bank of the Trent River, $4 \mathrm{~km}$ below the mouth of Clayhill Branch. The more arenaceous pelecypod-mold facies may be seen at the above-designated type locality, in the area of Whitford Landing at River Bend (loc. 37), and on the right bank, $0.4 \mathrm{~km}$ below the mouth of Miry Hole Branch (loc. 16), all on the Trent River.

The River Bend Formation crops out in Onslow, Jones, and Craven Counties, and Oligocene deposits probably referable to the River Bend are present in the subsurface in Carteret, Pamlico, Hyde, and Dare Counties.

The River Bend overlies the Castle Hayne Formation at the Martin Marietta quarry at New Bern (loc. 5). Here, a light-tan barnacle calcarenite deposit overlies a phosphate and Pycnodonte veneer on the very sandy Spring Garden Member of the Castle Hayne. The calcarenite deposit is overlain by a molluscan-mold biocalcirudite deposit, also belonging to the River Bend. The contact between the River Bend and the Castle Hayne is sharp 
and uneven; a slight angular unconformity is evident on the southwest wall of the quarry. The unconformable nature of the Castle Hayne-River Bend contact can also be seen at Prettyman Landing (loc. 44) on the Trent River where the mold and cast biocalcirudite deposits of the River Bend unconformably overlie the siliceous, very indurated limestone of the Spring Garden Member of the Castle Hayne. The two units are sharply separated by an uneven contact marked by a coarse basal conglomerate consisting of clasts as large as cobbles. In the New Bern area, the River Bend dips east and south. The stratigraphically higher sandier limestone dominates the surface outcrops from the River Bend area to Belgrade. Subsequent erosion and solution have beveled and cut channels into the indurated upper surface of the River Bend.

Overlying this surface and occupying the eroded channels from Pollocksville to Belgrade is a friable arenaceous Crassostrea bed of the Pollocksville Member of the Belgrade Formation (lower Miocene). To the east, the River Bend is directly overlain by the Haywood Landing Member of the Belgrade Formation, as at the Martin Marietta quarry at Belgrade (loc. 20).

Near the mouth of the Trent River, at Price Creek (loc. 18), the River Bend carbonate deposits are overlain by upper Miocene leached, clayey sands. In the Martin Marietta quarry at New Bern (loc. 5), the River Bend Formation is overlain partly by the shelly sand of the Duplin Formation and partly by tan and orange leached clean sand, which may represent the Pleistocene in the area.

The River Bend Formation ranges in age from middle Oligocene (late Vicksburgian) to late Oligocene (Chickasawhayan). The presence of Ficus mississippiensis Conrad, Oniscia harpula Conrad, Dentalium mississippiensis Conrad, Cardium diversum Conrad, and Chione imitabilis (Conrad) in the River Bend at the Martin Marietta Plant at New Bern (loc. 5) indicates a late Vicksburgian age. The calcarenite beds at the North Carolina Highway Department pit north of Pollocksville (loc. 12) on the Trent River are also believed to be late Vicksburgian in age on the basis of the abundance of Pecten perplanus byramensis Gardner. On the basis of ostracodes, J. E. Hazel (written commun., 1977) has determined that the higher sandy limestone beds of the River Bend are Chickasawhayan. Mollusks in this facies include Chlamys waynesis Mansfield, Anomia taylorensis Mansfield (a junior synonym of =Anomia ruffini Conrad), and many 
venerid species, which indicate a Chickasawhayan age. Also indicative of a post-Eocene age are the abundant remains of balanid barnacles. Barnacles are extremely rare to absent in the Eocene deposits on the Atlantic coast. However, in the Vicksburgian sediments, Hesperibalanus is extremely common.

The lower calcarenitic beds of the River Bend Formation have been found to be equivalent to the upper Vicksburgian Stage and specifically to the Byram Formation of Mississippi and Alabama. Beds of this age are found at the Martin Marietta quarry at New Bern (loc. 5) and along the Trent River from New Bern to Pollocksville.

The upper, very sandy beds containing abundant large molds of mollusks, especially venerids, are considered to be of Chickasawhayan Age and may be correlated with the upper beds of the Cooper Formation in South Carolina (Hazel, 1976), the Suwannee Limestone of Georgia and Florida, and the Chickasawhay Formation and Paynes Hammock Sand of Alabama and Mississippi (Poag, 1975). The upper beds of the River Bend Formation are also correlated with unnamed Chickasawhayan sediments along the Pamunkey and Chickahominy Rivers in Virginia.

\section{MIOCENE SERIES}

\section{BELGRADE FORMATION}

Beds herein assigned to the Belgrade Formation were not included by Miller $(1910,1912)$ in his definition of the Trent Marl, but Kellum $(1925,1926)$ considered them equivalent to beds on the Trent River below Pollocksville. Using the mollusks found in the Silverdale area, Kellum concluded that the Trent was early Miocene in age and included rocks now known to be middle Eocene and middle and late Oligocene in that age assignment. The sediments herein assigned to the Belgrade Formation represent a distinct and sharply contrasting lithology and are deserving of formational rank.

The Belgrade Formation consists usually of unconsolidated, very arenaceous shell beds of two lithologies-a tan, somewhat leached, very arenaceous oyster (Crassostrea) member and a moderately phosphatic (as much as 15 percent), slightly calcareous, silty, arenaceous shell member containing occasional, thinly laminated olive clays.

The Belgrade Formation crops out from the mouth of the White Oak River to Belgrade, Onslow County, and north to 
Pollocksville in Jones County. Quarries expose B grade beds 3 $m$ thick or more in the vicinity of Silverdale, and small exposures are known along the White Oak River and in the Croatan National Forest.

The Belgrade is named for deposits found in the area of Belgrade, Jones County, and is well exposed at the type locality, the Martin Marietta quarry (loc. 20).

The Belgrade Formation overlies the River Bend Formation unconformably, and it progressively overlaps older sediments of the River Bend from Belgrade to Pollocksville. The Belgrade Formation is divided into two members-the Pollocksville and the Haywood Landing.

\section{POLLOCKSVILLE MEMBER}

The Pollocksville Member consists of a leached, tan to orange, unconsolidated very arenaceous Crassostrea bed, which has been described by Lawrence (1975). It reaches a maximum thickness of $3 \mathrm{~m}$. This member crops out from Belgrade to Pollocksville and along the Trent River in that area.

The Pollocksville Member is named for excellent exposures of this bed in the vicinity of that town, where, at the type locality along the Trent River (loc. 8), $4 \mathrm{~m}$ crops out.

In its type locality, the Pollocksville unconformably overlies an uneven and eroded River Bend Formation surface. Here, the River Bend consists of a moderately arenaceous to calcarenitic limestone of Vicksburgian Age. In the vicinity of Belgrade, the Pollocksville overlies, and occupies channels in, the very hard eroded surface of the River Bend.

We believe that the Pollocksville Member was deposited in early Miocene time. The earliest deposition somewhat preceded that of the Haywood Landing Member, but the two members were, in part, penecontemporaneous. The large fossil assemblage in the Haywood Landing Member indicates that it and also the Pollocksville are age equivalents of the Tampa Limestone (lower Miocene) of Florida. Giant oysters of the species found in the Pollocksville are common in the lower Miocene part of the Catahoula Sandstone of Mississippi and Alabama. The Crassostrea are also found in a silty, sandy bed just below the weathered, burrowed sands of the Hawthorn Formation at Shell Bluff, Ga. The section at Shell Bluff shows approximately the same sequence found in the Coastal Plain of North Carolina-coarse crossbedded calcareous sands of Claibornian Age overlain by a middle to 
upper Oligocene siliceous limestone. A silty Crassostrea bed overlies the Oligocene and is in turn overlain by orange to tan, burrowed, mottled sands of the Hawthorn (middle Miocene).

Although Crassostrea is found in the upper Chickasawhayan sediments of the River Bend Formation, we believe that the oysters of the Pollocksville Member and at Shell Bluff represent the early Miocene appearance of Crassostrea gigantissima (Finch).

\section{HAYWOOD LANDING MEMBER}

The Haywood Landing Member usually consists of unconsolidated, gray to brown, moderately phosphatic, and, in some areas, somewhat calcareous, clayey, very shelly quartz sands. These shells occasionally constitute more than 50 percent of the bed and range from leached to excellently preserved material. In the western wall of the Martin Marietta quarry at Belgrade (loc. 20), the sandy shell deposit grades upward into a laminated olivegreen clay. This clay bed has not been traced beyond the quarry but may represent a quiet lagoonal facies of the Haywood Landing Member.

The Haywood Landing Member is approximately $3 \mathrm{~m}$ thick at Belgrade, at Haywood Landing (loc. 21) on the White Oak River, and in the borrow pits at Silverdale (loc. 22). Brown and others (1972) included beds here assigned to the Belgrade Formation in their maps and sections of the Oligocene. Their plate 26 includes a core section (NC-CR-OT-30) that shows beds of Haywood Landing lithology at the interval of $25.4 \mathrm{~m}$ to approximately $57 \mathrm{~m}$, giving a total thickness of approximately $31 \mathrm{~m}$ in this far southeastern section of Craven County. The Haywood Landing Member is in the shallow subsurface in the Bogue Inlet and New River Inlet areas.

The Haywood Landing Member is named for a small outcrop (the only known natural outcrop) at Haywood Landing on the Trent River, Jones County, its type locality (loc. 21). A supplementary reference locality is at the Martin Marietta Co. quarry at Belgrade (loc. 20).

The Haywood Landing Member apparently overlies the limestone of the River Bend Formation in its entire geographic area. However, this relationship is only well exposed in the walls of the Martin Marietta quarry at Belgrade (loc. 20). In the southeastern wall, the Haywood Landing overlies an oyster-covered, thin phosphatic veneer on the surface of the River Bend indurated biocalcirudite beds. In the northwestern corner of the pit at 
Belgrade, a 15-cm-thick shelly deposit of Duplin age overlies the olive clay bed of the Haywood Landing.

The Haywood Landing Member is the offshore, open-marine equivalent of the Pollocksville Member. The Haywood Landing contains a very large molluscan fauna that shares many forms with the Tampa Limestone in Florida.

\section{LOCALITY REGISTER}

1. Biddle Landing, right bank of Neuse River, $3.2 \mathrm{~km}$ north of Ft. Barnwell, Craven County, N.C.

2. $180 \mathrm{~m}$ above Rock Landing at mouth of Turkey Quarter Creek, right bank of Neuse River, Craven County, N.C.

3. Rock Landing, $4 \mathrm{~km}$ north of Jasper, right bank of Neuse River, Craven County, N.C.

4. Spring Garden Landing, $5.2 \mathrm{~km}$ east-northeast of Jasper, right bank of Neuse River, Craven County, N.C.

5. Martin Marietta Co., New Bern quarry, northwest of New Bern, $0.8 \mathrm{~km}$ northeast of Route 55 on County Road 1402, Craven County, N.C.

6. Right bank of Neuse River below New Bern just below $(50 \mathrm{~m})$ mouth of Trent River, Craven County, N.C.

7. Left bank of Trent River, $1.2 \mathrm{~km}$ above Pollocksville, just below abanoned railroad trestle, Jones County, N.C.

8. Left bank of Trent River next to Seaboard Coastline Railroad trestle, Pollocksville, Jones County, N.C.

9. Small pit on left bank of Mill Creek at Route 1004 bridge over Mill Creek, just north of road, Jones County, N.C.

10. Small borrow pit, $0.3 \mathrm{~km}$ south of railroad trestle over Trent River, just east of railroad tracks, Pollocksville, Jones County, N.C.

11. Right bank of Trent River, $0.4 \mathrm{~km}$ below mouth of Clayhill Branch, Jones County, N.C.

12. N.C. Highway Dept. borrow pit, $4 \mathrm{~km}$ north-northeast of Pollocksville on left bank of Trent River, Jones County, N.C.

13. Right bank of Trent River, $0.5 \mathrm{~km}$ below mouth of Raccoon Creek, Jones County, N.C.

14. Simmons borrow pit, left bank of Trent River, $0.5 \mathrm{~km}$ above mouth of Scott Creek, Jones County, N.C.

15. Debruhls Landing, left bank of Trent River, Jones County, N.C.

16. Right bank of Trent River, $0.4 \mathrm{~km}$ below mouth of Miry Hole Branch, Jones County, N.C.

17. Abandoned borrow pit on right bank of Brice Creek, $3.2 \mathrm{~km}$ southwest of James City, Craven County, N.C.

18. Right bank of Trent River, just below mouth of Brice Creek, $1.6 \mathrm{~km}$ southwest of James City, Craven County, N.C.

19. Abandoned quarry, $1.6 \mathrm{~km}$ south of Maysville, just east of Route 17 and just north of White Oak River, Jones County, N.C.

20. Martin Marietta Co., Belgrade Quarry, just east of intersection of Route 1434 and U.S. 17, Belgrade, Onslow County, N.C.

21. Haywood Landing, left bank of White Oak River, $1.2 \mathrm{~km}$ below mouth of Holston Creek, Jones County, N.C. 
22. Silverdale Marl Company quarry at Silverdale, $0.4 \mathrm{~km}$ southeast of intersection of Routes 1434 and 1442, Onslow County, N.C.

23. Right bank of New River at Hines Point, Onslow County, N.C.

24. Right bank of New River, $0.8 \mathrm{~km}$ above Catfish Point, Onslow County, N.C.

25. Right bank of New River, $0.4 \mathrm{~km}$ above mouth of Mill Creek, Onslow County, N.C.

26. Left bank of New River, $0.4 \mathrm{~km}$ below mouth of Goose Creek, Onslow County, N.C.

27. N.C. Lime Excavating Co. quarry, $6.4 \mathrm{~km}$ west of Comfort, just north of Route 41, Jones County, N.C.

28. Billy B. Fussel Company, Inc., Quarry, Box 400, Rose Hill, $1.6 \mathrm{~km}$ west of Rose Hill on Route 1102, Duplin County, N.C.

29. Atlantic Limestone Company Quarry, $4 \mathrm{~km}$ south-southeast of Magnolia, just east of Route 117, Duplin County, N.C.

30. East Coast Limestone Company Quarry, $2.4 \mathrm{~km}$ west of Maple Hill, $1.6 \mathrm{~km}$ southwest of intersection of Routes 53 and 50, Pender County, N.C.

31. Martin Marietta Co., Castle Hayne quarry, $2.8 \mathrm{~km}$ east of Castle Hayne, $0.8 \mathrm{~km}$ north of Route 1002, New Hanover County, N.C.

32. Ideal Cement Co. quarry, $4 \mathrm{~km}$ east of Castle Hayne, north of Route 1002 at end of Route 2023, New Hanover County, N.C.

33. Martin Marietta Co., Georgetown quarry, $4.8 \mathrm{~km}$ west-northwest of Jamestown, just west of Route 17A, Georgetown County, S.C.

34. Martin Marietta Co., Cross quarry, $2.4 \mathrm{~km}$ south of Routes 6 and 59 intersection, Berkeley County, S.C.

35. Giant Portland Cement Co. quarry, $3.2 \mathrm{~km}$ north of Harleyville, just east of Route 453, Dorchester County, S.C.

36. $0.3 \mathrm{~km}$ below mouth of Mill Creek on right bank of Trent River, Jones County, N.C.

37. Whitford Landing, right bank of the Trent River at River Bend, Jones County, N.C.

38. $0.3 \mathrm{~km}$ above Rhems Landing, left bank of Trent River, just below River Bend, Craven County, N.C.

39. Lanes Ferry Park, right bank of the Northeast Cape Fear River, just below the Route 210 bridge, Pender County, N.C.

40. Right bank of Trent River $1.2 \mathrm{~km}$ southwest of Comfort Depot, Jones County, N.C., on farm of Miss Sally Simmons. In a vertical bluff 7.6 $\mathrm{m}$ high, extending for $150 \mathrm{~m}$ along the right side of the river.

41. Right and left banks of New River, just above and below the Route 1316 bridge, Onslow County, N.C.

42. $0.3 \mathrm{~km}$ below Route 1316 bridge over the New River on the left bank, just downstream from the small falls over limestones of the Comfort Member of the Castle Hayne Formation, Onslow County, N.C.

43. Natural well, $2.9 \mathrm{~km}$ southwest of Magnolia, just east of Route 1003, Duplin County, N.C.

44. Prettyman Landing, left bank of the Trent River, Jones County, N.C.

45. Pine Hollow Golf Course, just east of the Wake-Johnston County line, just north of Route 1004, Johnston County, N.C.

46. $2 \mathrm{~km}$ upstream from the Route 111 bridge over the Neuse River on the right bank, Wayne County, N.C.

47. $0.8 \mathrm{~km}$ above the Route 55 bridge over Moseley Creek on the right and left banks of the creek, Craven and Lenoir Counties, N.C. 


\section{DESCRIPTIONS OF TYPE AND SUPPLEMENTARY SECTIONS}

Locality 4.-Craven County (type locality of Spring Gardem Member of Castle Hayne Formation)

Thickness

(meters)

Root-covered soil and rock (inaccessible)

1.75

Castle Hayne Formation (middle Eocene) :

Spring Garden Member (uppermost middle Eocene) :

Molluscan-mold biocalcirudite, light-gray $(N 7)^{3}$, very sandy, in micrite matrix; sand-sized phosphate common; molds iron stained and commonly partly or completely filled by silica

Sea level

Locality 5.-Craven County (reference locality of Spring Garden Member of Castle Hayne Formation; reference locality of River Bend Formation)

[Altitude at top of plt is $5 \mathrm{~m}$ above sea level]

Thickness

(meters)

Soil

Croatan Formation (lower Pleistocene and upper Pliocene) :

Fine sand, tan to orange, somewhat massive near base and grading

to crossbedded above

Duplin Formation (lower Pliocene) :

Phosphate-shell bed, tan to orange, sandy; some bones, teeth along contact

River Bend Formation (upper and middle Oligocene) :

Gastropod biocalcirudite, light-gray $(N 7)$, in matrix; very small amounts of very fine sand

Barnacle calcarenite, light-yellowish-gray $(5 Y$ 7/2); few small mollusks

Large pycnodonts common, adhering to thin $(6 \mathrm{~mm})$ black phosphate coating

Castle Hayne Formation (middle Eocene) :

Spring Garden Member (uppermost middle Eocene) :

Molluscan-mold biocalcirudite, light-gray $(N 7)$, very sandy, very hard, slightly phosphatic; some siliceous infilling; very many molds, some in living position

Molluscan-mold biocalcirudite, light-gray $(N 7)$, very sandy, moderately hard, slightly phosphatic; very many bivalve molds, some in living position

Quarry floor

${ }^{3}$ Color designations are based on the "Rock-Color Chart" of the National Research Councll (Goddard and others, 1948). 
Locality 8.-Jones County (type locality of Pollocksville Member of Belgrade Formation)

Sloped and plant-covered (inaccessible)

Thickness

(meters)

Belgrade Formation (lower Miocene) :

Pollocksville Member (lower Miocene) :

Crassostrea bed, grayish-orange (10YR 7/4), weathered, very sandy; oysters very rotten

Sea level

Locality 11.-Jones County (reference locality of River Bend Formation)

Thiokness
(meters)

Covered by vegetation and sloped (inaccessible) -............. 2.5

River Bend Formation (upper and middle Oligocene) :

Molluscan-mold biocalcirudite, grayish-orange $(10 Y R \quad 7 / 4)$, very sandy

Calcirudite, grayish-orange (10YR 7/4), slightly sandy, friable, fine; some small molds; small pectens common (Pecten trentensis, $P$. byramensis)

Sea level

Locality 13.-Jomes County (reference locality of River Bend Formation)

Covered by vegetation

River Bend Formation (upper and middle Oligocene) :

Molluscan-mold biocalcirudite, pale-yellowish-orange $(10 Y R 8 / 6)$, very sandy. Many large bivalve molds in excellent shape; very hard and indurated

Barnacle-fragment biocalcirudite, grayish-orange $(10 Y R \quad 7 / 4)$, slightly sandy, steeply current bedded $\left(45^{\circ}\right)$, somewhat friable and less indurated; bivalve molds common

Locality 20.-Onslow County (type locality of Belgrade Formation; reference locality for its Haywood Landing Member)

[Altitude at top of soll is $\mathbf{1 0} \mathrm{m}$ above sea level]

Sand, crossbedded, fine, tan

Discoidal pebble lag on Duplin surface 
Belgrade Formation (lower Miocene) :

Haywood Landing Member (lower Miocene) :

Disconformity, uneven surface, thinly laminated green clay interbedded with shell bed below

Shell bed, slightly calcareous, very phosphatic, very sandy, slightly clayey; many preserved mollusks, most water-worn; bones, teeth

Oyster community adhering to phosphate

Phosphate-coated surface, irregular, uneven

River Bend Formation (upper and middle Oligocene) :

Molluscan-mold biocalcirudite, light-gray $(N 7)$, very sandy, very hard, coarse; small amounts of very fine phosphate in a micrite matrix. Molds sometimes partially filled with $\mathrm{Si}$ or $\mathrm{CaCO}_{3}$. Many large Mercenaria molds

Sand, tan, fine, calcareous, friable

Molluscan-mold calcirudite, medium-gray (N5), medium-grained, in micrite matrix; small amounts (5-10 percent) very fine quartz sand

Mollusk molds, mostly fragmentary; some preserved Pecten, Anomia, many barnacle plates

$$
\text { Grades into } \uparrow
$$

Quartz arenite, light-gray (N7), somewhat calcareous, containing abundant preserved Anomia, some Pecten, barnacles

\section{Grades into}

Molluscan-mold calcirudite, tan to light-gray (N7), very sandy, crumbly; molds mostly gastropods, Balanus common

\section{Quarry floor}

\section{Locality 21.-Jones County (type locality of Haywood Landing Member of Belgrade Formation)}

I A small exposure of shelly sand on this otherwise (avered and overgrown bank of the White Oak River is considered to be the type locility for the Haywood Landing Member of the Belgrade Formation because it is the only known natural outcropl

Belgrade Formation (lower Miocene) :

Thickness (meters)

Haywood Landing Member (lower Miocene) :

Shell bed, $\tan$ to orange, sandy; weathered on surface but has fresher shell several inches into exposure; many well-preserved bivalves and gastropods; phosphatic sand throughout

\section{Locality 27.-Jones County (type locality of Comfort Member of Castle Hayne Formation)}

[Land surface is $20 \mathrm{~m}$ above sea level] 
Pleistocene(?) deposits :

Sand, tan, fine

Clay, dark-gray, sticky, soft

Eocene(?) deposits:

Sand, orange, leached; many small molds

Castle Hayne Formation (middle Eocene) :

Comfort Member (upper middle Eocene) :

Bryozoan and foraminiferal calcarenite, light-gray $(N 7)$ to yellowish-gray (5Y 8/1), medium-grained. Abundant pectens, especially near top; small echinoids common

Grades into

Bryozoan biocalcirudite, light-gray (N7), fine, slightly glauconitic. Consists mainly of ground-up and sorted bryozoan and echinoidal fragments; whole echinoids common, other macrofossils rare; large Foraminifera abundant. Contact below burrowed, marked by rubble of cobble-sized, phosphate- and glauconite-coated clasts

Shelly calcarenite, yellowish-gray $(5 Y \quad 7 / 2)$, very glauconitic (5-10 percent), moderately sandy (very fine, clear, angular). Macrofossils common, abundant in pockets; pectens predominant, echinoids common

Quarry floor

Locality 31.-New Hanover County (type locality of New Hanover Member of Castle Hayne Formation; reference locality of Comfort Member of Castle Hayne)

[Land surface is approximately $3 \mathrm{~m}$ above sea level]

Pleistocene(?) deposits:

Sand, tan to orange, coarse to medium, massive

Sand, dark-gray humate, containing logs, roots, stumps

Castle Hayne Formation (middle Eocene) :

Comfort Member (upper middle Eocene) :

Massive to crossbedded, tan, bryozoan fine biocalcirudite to tan biomicrite; molluscan molds

New Hanover Member (middle middle Eocene) :

Lithocalcirudite, sandy, phosphatic, glauconitic, conglomeratic, coarse, in very light gray micrite matrix

Peedee Formation (Upper Cretaceous) :

Molluscan-mold biosparrudite, very sandy, very many bivalve molds Biosparrudite, alternating with loose quartz arenite 
Locality 32.-New Hanover County (type locality of Castle Hayne Formation; reference localities of its New Hanover and Comfort Members)

[Land surface is approximately $7 \mathrm{~m}$ above sea level]

Pleistocene(?) deposits:

Sand and clayey sand, $\tan$ to orange, filling solution-pocked upper surface of underlying limestone

Clay (residue of dissolved limestone), green, containing glauconite and phosphate near base

Castle Hayne Formation (middle Eocene) :

Comfort Member (upper middle Eocene) :

Biocalcarenite, tan, soft

Calcarenite, tan, hard, containing burrows filled with fine shell --

Biocalcarenite, tan, soft

Calcarenite, tan, hard, containing burrows filled with fine shell --

Biocalcarenite, tan, soft

0.5

Calcarenite, tan, hard, containing burrows filled with fine shell --

Biocalcarenite, yellow-gray $(5 Y 8 / 1)$, fossiliferous, soft and friable; fossils mainly molds of mollusks, some calcitic forms preserved, many bryozoans; glauconitic, limy nodules, indicating possible diastem

Bryozoan dense micrite, very light gray (N8), fine, some molds, glauconite, phosphate; upper surface irregular, phosphate coated

Crossbedded, light-gray (N7), fine bryozoan biocalcirudite to medium calcarenite in micrite matrix

New Hanover Member (middle middle Eocene) :

Lithocalcirudite, sandy, phosphatic, glauconitic, in very light gray (N8) micrite matrix

Peedee Formation (Upper Cretaceous) :

Molluscan-mold biocalcirudite, light-gray (N7), sandy, cemented by calcite spar

\section{Quarry floor}

Locality 38.-Craven County (type locality of River Bend Formation)

Sloped and covered

River Bend Formation (upper and middle Oligocene) :

Molluscan-mold biocalcirudite, yellowish-gray $(5 Y 7 / 2)$, indurated but partially friable, very sandy. Small amounts of phosphatic sand; very many molluscan molds, mostly Mercenaria 


\section{REFERENCES CITED}

Brown, P. M., 1955, Stratigraphic revision of the Trent marl of North Carolina [abs.]: Geol. Soc. America Bull., v. 66, no. 12, pt. 2, p. 1686.

Brown, P. M., Miller, J. A., and Swain, F. M., 1972, Structural and stratigraphic framework, and spatial distribution of permeability of the Atlantic Coastal Plain, North Carolina to New York: U.S. Geol. Survey Prof. Paper 796, 79 p.

Cooke, C. W., and MacNeil, F. S., 1952, Tertiary stratigraphy of South Carolina: U.S. Geol. Survey Prof. Paper 243-B, p. 19-29.

Goddard, E. N., and others, 1948, Rock-color chart: Washington, D.C., Natl. Research Council, 6 p. (Republished by Geol. Soc. America, 1951, reprinted 1970.)

Hazel, J. E., 1976, Cooper Marl in the Coastal Plain of South Carolina and Georgia, in Cohee, G. V., and Wright, W. B., Changes in stratigraphic nomenclature by the U.S. Geological Survey, 1975: U.S. Geol. Survey Bull. 1422-A, p. 54-55.

Kellum, L. B., 1925, The age of the Trent Marl in North Carolina: Jour. Geology, v. 33, no. 2, p. 183-187.

1926, Paleontology and stratigraphy of the Castle Hayne and Trent marls in North Carolina: U.S. Geol. Survey Prof. Paper 143, 56 p.

Lawrence, D. R., 1975, Paleoenvironmental setting of Crassostrea gigantissima (Finch) communities, coastal plain of North Carolina: Southeastern Geology, v. 17, no. 2, p. 55-66.

LeGrand, H. E., and Brown, P. M., 1955, Guidebook of excursion in the coastal plain of North Carolina, October 8-9, 1955: Carolina Geol. Soc., $43 \mathrm{p}$.

Miller, B. L., 1910, Erosion intervals in the Tertiary of North Carolina and Virginia: Geol. Soc. America Bull., v. 20, p. 673-678.

1912, The Tertiary formations in Clark, W. B., and others, The coastal plain of North Carolina: North Carolina Geol. and Econ. Survey Bull., v. 3, p. 171-258.

Poag, C. W., 1972, Planktonic foraminifers of the Chickasawhay Formation, United States Gulf Coast: Micropaleontology, v. 18, no. 3, p. 257-277. 1975, The Chickasawhay Stage: Gulf Coast Assoc. Geol. Socs., 25th Meeting, Field Trip Guidebook, p. 87-111. 

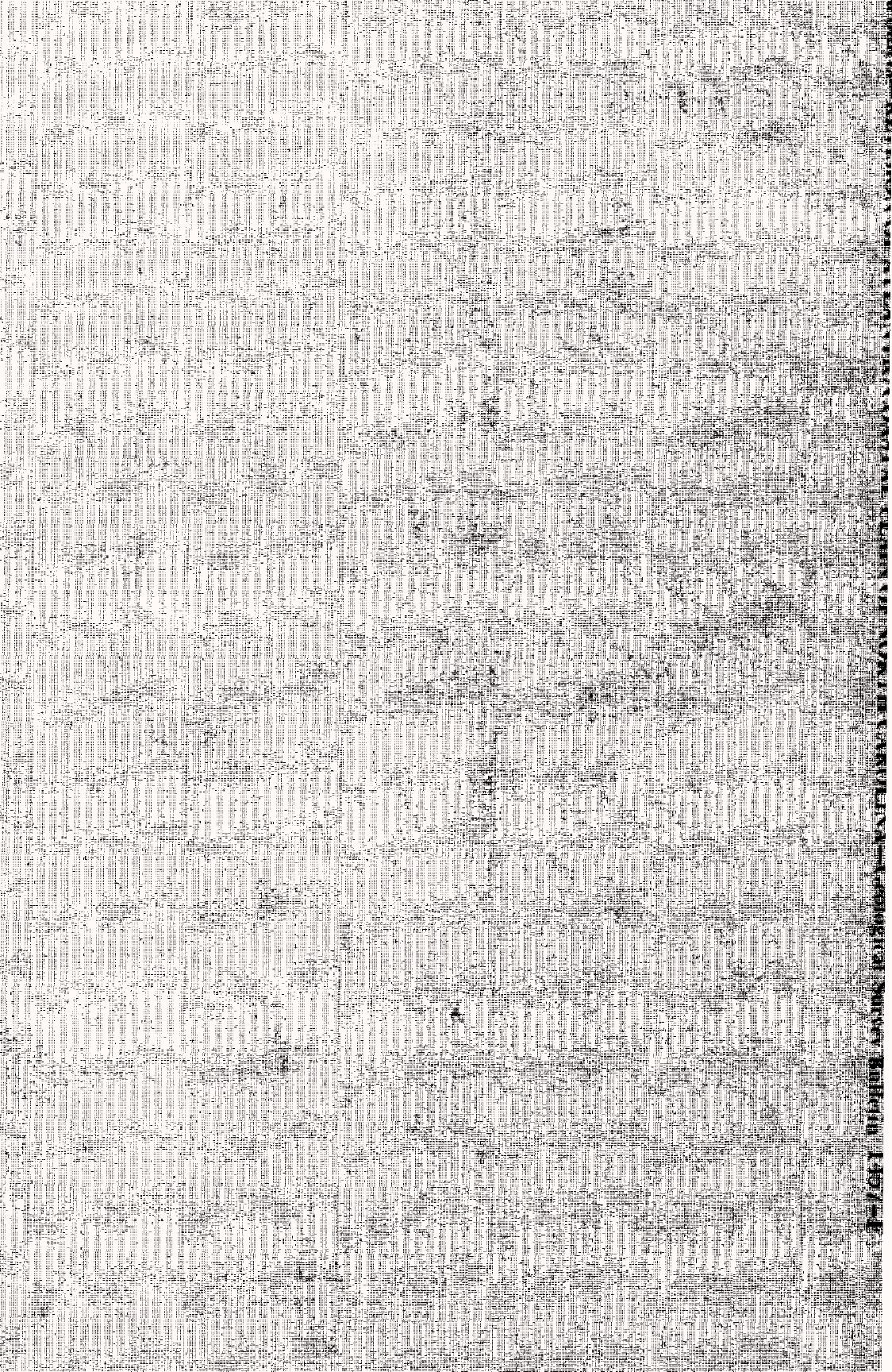